Wacław Cockiewicz

Uniwersytet Jagielloński, Kraków

wcockiewicz@interia.pl

\title{
O WIERNOŚCI I UCIAZŻLIWOŚCI, A O METAFORZE CAŁKIEM PRZY OKAZJI (ODPOWIEDŹ NA KRYTYKĘ PANI PROFESOR ELŻBIETY MUSKAT-TABAKOWSKIEJ)
}

Słowa klucze: analiza, Leśmian, metafora, metody badawcze, teoria Keywords: analysis, Leśmian, metaphor, research methods, theory

Wszystko źle. Dlaczego wszystko źle? Bo autor ośmielił się skrytykować kognitywną teorię metafory, twierdząc, że ona się nie nadaje na podstawę do opracowania procedury analitycznych, materiałowych badań wyrażeń metaforycznych. Takie wrażenie odnosi się po lekturze artykułu Prof. Elżbiety Muskat-Tabakowskiej pod intrygującym tytułem Pies wierny, ale uciążliwy, czyli o metaforze (Leśmiana i nie tylko), w którym autorka poddaje kompleksowej ( $\mathrm{w}$ różnych odcieniach znaczeniowych tego przymiotnika) krytyce moją książkę o metaforyce Leśmiana.

Każdy ma prawo oceniać to, co czyta, jak mu serce dyktuje. Wygląda na to, że Pani Profesor z tego prawa skorzystała i napisała swoją miażdżąco surową recenzję (w zewnętrznej formie artykułu polemicznego) pod dyktando serca. Pisanie pod jakiekolwiek dyktando rzadko wychodzi na dobre, a serce ma to do siebie, że czasem zakłóca optykę, czyli przeszkadza w czytaniu, nie pozwalając dostrzec tego, co w tekście jest, i każąc odkrywać to, czego w nim nie ma.

Nie odpowiem tu na wszystkie szczegółowe zarzuty mojej Szanownej Polemistki, choćby dlatego, że mam na to (z techniczno-wydawniczych powodów) kilka dni, podczas gdy ona sama miała na ich sformułowanie (co najmniej) ponad dwa miesiące (licząc od mojego wystąpienia, o którym pisze w swoim artykule). Czasami 
też utrudnia mi to zadanie stawiająca zarzut Autorka. Jakże bowiem miałbym się szczegółowo ustosunkować do następującego jej twierdzenia, które ma rzekomo falsyfikować postawioną przeze mnie tezę, że brakuje materiałowych prac analitycznych o metaforze (mimo że teoretycznych jest bardzo dużo), skoro Pani Profesor (celowo?) nie ujawnia, jakie prace ma na myśli?

[...] nie sięgając już do prac badaczy zagranicznych, warto wspomnieć chociażby o takich autorach, jak Elżbieta Wójcik-Leese, Agnieszka Libura, Dorota Korwin-Piotrowska czy Ewa Sławkowa (s. 283).

Spośród czterech wymienionych tu nazwisk polskich autorek przychodzi mi do głowy (jako ewentualny referent) książka D. Korwin-Piotrowskiej (2006) i artykuł A. Libury (1998). Oba teksty zdecydowanie kognitywistyczne, ale o żadnym nie da się powiedzieć, że to praca analityczna. Trudno za taką uznać rozprawę, która nawet w tytule ma „na przykładach”. Ja swoją tezę w odniesieniu do prac kognitywistycznych w książce uzasadniłem, wskazując na to, że teoria ta nie daje niezbędnego kryterium do wyodrębnienia wyrażeń metaforycznych z korpusu tekstowego, czyli do rozpoznania ich jako metaforycznych, co jest warunkiem nieodzownym przeprowadzenia systematycznej analizy tekstu pod tym względem (zawartości w nim metafor), a zilustrowałem ją przykładem pracy zagranicznego badacza, powszechnie w Polsce znanej dzięki tłumaczeniu (Pani Profesor jest w komitecie redakcyjnym tej edycji). Jej autor deklaruje wprawdzie przeprowadzenie materiałowych badań, ale ani nie przedstawia zastosowanej procedury badawczej, ani nie pokazuje przeanalizowanego materiału, lecz tylko omawia jego rezultaty (Jäkel 1997/2006). Taką pracę - nawet uznając na podstawie deklaracji autora jej materiałowy charakter - można w najlepszym wypadku nazwać syntetyczną, ale nie analityczną. Być może różnimy się z Panią Profesor co do rozumienia treści pojęć analiza, analityczny.

Żeby zdemaskować rzekomą moją niekonsekwencję, E. Tabakowska przypomina złożone w pierwszym zdaniu mojej książki oświadczenie, że to nie jest praca o metaforze, tylko o Leśmianie, a następnie - jakby nie dostrzegając jego retorycznego charakteru (czyżby wyraźny wpływ nadmiaru sercowej optyki?) - całkiem na serio dowodzi, że, owszem, książka jest przecież o metaforze, a robi to za pomocą cytatu z jej końca, preparując go w taki sposób, że zupełnie znika właściwy sens tego fragmentu, a to, co pozostaje, zdaje się potwierdzać jej tezę (że książka jest o metaforze). Przytaczam ten fragment bez wewnętrznych cięć, zaznaczając (wytłuszczoną czcionką) fragmenty opuszczone przez Autorkę artykułu.

[...] metaforyka w twórczości Bolesława Leśmiana wykazuje wyraźne cechy systemowości, zarówno na poziomie semantycznym, którego zasadniczo dotyczy, jak i na poziomie składniowym, gdzie manifestuje się w postaci konkretnych wyrażeń metaforycznych. Jej funkcja w obrębie repertuaru językowego poety - subkodu poetyckiego, da się porównać do funkcji konceptualnej metafory systemowej (językowej) w języku naturalnym. Polega ona na uzupełnianiu (inopiae causa) tych obszarów 
semantycznych, które nie mają swoich korelatów językowych - w przypadku metafory językowej w niemetaforycznym zasobie wyrażeń kodu naturalnego, w przypadku zaś subkodu poetyckiego w słownictwie i frazeologii (a po części też w gramatyce) języka standardowego. Metaforyka Leśmiana jest zatem [...] ważnym i systemowo zorganizowanym środkiem służącym do wzbogacenia języka [...] (Cockiewicz 2013: 230-231).

W tekście powiedziane jest zatem, że funkcja metafory u Leśmiana jest podobna do tej, jaką w języku naturalnym pełnią odkryte w nim przez badaczy kognitywistycznych konceptualne metafory „dosłowne”, a Autorka w polemicznym zapale widzi w tym dowód przyznania się, że książka jest, wbrew (pozornej przecież, retorycznej) deklaracji, jednak o metaforze w ogóle. Absurdem byłoby, gdybym twierdził, że moja książka nie jest w ogóle o metaforze. Oczywiście, że jest o metaforze, zaś owo nieszczęsne sformułowanie jest wyłącznie ekspresją intencji badawczej autora książki, że jego celem jest analiza metaforyki Leśmiana, a nie zasadnicza rozprawa na temat metafory.

$\mathrm{Na}$ podobnym nieporozumieniu polega zawarte w zdaniu następującym bezpośrednio po tym cytacie twierdzenie Autorki przypisujące mi pogląd, że metafora jest „immanentną cechą struktury języka” i podobnie jak poprzednio jest zupełnie mechanicznym wyrwaniem z kontekstu tego wyrażenia. Fragment ten w tekście mojej książki referuje poglądy George’a Lakoffa i Marka Johnsona, interpretowane na s. 9 polskiego wydania przez tłumacza ich książki, i brzmi tak:

Zapoczątkowane w roku 1980 klasyczną już dziś pracą Georga Lakoffa i Marka Johnsona zainteresowanie metaforą ze strony lingwistyki kognitywnej skupiało się na leżącym u podstaw języka i poznawalnym poprzez jego badanie „systemie pojęciowym”, któremu przypisują oni charakter metaforyczny właśnie, charakteryzujący nasze schematy myślenia i postępowania. Stosownie do tych założeń badaną przez siebie metaforę nazywają pojęciową, względnie konceptualną. Jest ona zatem immanentną cechą struktury języka, nie zaś intencjonalnie tworzoną konstrukcją charakteryzującą styl wypowiedzi: utworu literackiego, autora, określonego typu dyskursu itp. (Cockiewicz 2013: 8).

Fragment ze wstępu Tomasza P. Krzeszowskiego, do którego nawiązuje ten passus mojej pracy, brzmi zaś tak:

Książka bardzo wyraźnie uświadamia czytelnikowi wszechobecność metafory, fakt, że w codziennym posługiwaniu się językiem nie możemy wypowiedzieć zdania bez wyrażeń metaforycznych (Lakoff, Johnson 1988: 9).

Potem Autorka wyraźnie już przekracza standardy uczciwej polemiki, kiedy pisze:

Cockiewicz przywołuje - za twórcami kognitywnej teorii metafory (Lakoff, Johnson 1980/1988) - ogólnie przyjmowaną opozycję między „dosłownym” i „przenośnym” charakterem wyrażeń językowych. Na podstawie tej opozycji tworzy jednak (wewnętrznie sprzeczne) pojęcie „metafory dosłownej (s. 284) 
Jako odpowiedź na ten zarzut przytoczę fragment z polskiego tłumaczenia książki autorów kognitywnej teorii metafory, w którym pisząc o podgatunkach „metafory obrazowej (lub niedosłownej)", wyróżniają jako jeden z nich:

Przypadki nie wykorzystanej części metafory dosłownej ${ }^{1}$, np. „Jego teoria to tysiące pokoików i długich, krętych korytarzy" (Lakoff, Johnson 1988: 78, wyróżn. W. C.).

Sądzę, że dalszego komentarza kwestia ta nie wymaga.

Domaga się natomiast (i to pilnie) komentarza inne fundamentalne nieporozumienie, które świadczy o tym, że Autorka polemiki nieuważnie czytała nie tylko moją książkę. Pisze bowiem:

Można też przypuszczać, że Autor nie uznaje wagi rozróżnienia między metaforą pojęciową (będącą efektem rzutowania między dwiema domenami poznawczymi) i metaforą obrazową (opartą na podobieństwie między dwoma obiektami) - dychotomii postulowanej już w klasycznej pracy George’a Lakoffa (s. 285).

Rzecz w tym, że autorzy ci takiej opozycji nie „postulują”. Przeciwnie, na stronie 78 (polskiego wydania), z której pochodzi cytowany wyżej fragment, wyróżniają

[...] trzy podgatunki metafory obrazowej: rozszerzenie wykorzystanej części metafory [...] przypadki nie wykorzystanej części metafory dosłownej [podkr. W. C.] [...] przypadki nowej metafory, to znaczy metafory nie używanej do nadawania struktury zwykłemu systemowi pojęć (Lakoff 1980/1988: 78).

Wynika z tego niezbicie - abstrahując od niejasnej różnicy między pierwszym i drugim z wyróżnianych podgatunków, że obydwa to obrazowe metafory pojęciowe, a tylko trzeci przeciwstawia się co do swojej natury metaforze konceptualnej.

Pani Profesor zarzuca mi „niechęć do teorii kognitywnej” i wskazuje na moje pozytywne sformułowania pod jej adresem jako na rzekome niekonsekwencje. W przypisie stawia mi też zarzut ironicznego tonu. Oświadczam zatem, bez cienia ironii, że nie żywię żadnej niechęci do kognitywnej teorii metafory, dostrzegam i doceniam jej niewątpliwe zalety, ale widzę też wady, do których należy to, że nie definiuje licznych terminów, które wprowadza, tylko je opisuje, co ją pozbawia waloru dowodowego, i to, że nie jest przydatna do badania materiałowego, ponieważ nie daje kryterium, które by pozwoliło poznać, co w tekście jest metaforą, a to jest nieodzownym pierwszym krokiem takich badań. Formułując ten swój zarzut, Prof. E. Tabakowska wygłasza opinię, że moja krytyka teorii kognitywnej (za jej aprioryczny kierunek wnioskowania: od intuicyjnie tworzonego modelu teoretycznego do przykładów potwierdzających jego adekwatność) świadczy o niezrozumieniu nie

1 T.P. Krzeszowski we wstępie tłumacza na s. 8 proponuje zręczniejsze znacznie określenie metafora konwencjonalna (Lakoff, Johnson 1988: 8), które odpowiada stosowanemu przeze mnie (za Ryszardem Tokarskim) terminowi metafora językowa. 
tylko fundamentalnych zasad językoznawczego kognitywizmu, ale także - w dziedzinie badań nad teorią metafory - „o ignorowaniu roli, jaką odgrywają w nich badania korpusowe" (s. 285). Autorka nie wyjaśnia, na czym owo niezrozumienie miałoby polegać, a już zupełnie nieuzasadniona jest sugestia, że ma to jakikolwiek związek z ignorowaniem badań korpusowych. Co komu po korpusie, jak nie wiadomo, na jakiej zasadzie się z niego wydobywa to, co się chce badać? Ten przytyk odbieram tak, jak gdyby mi ktoś zarzucał, że krytykując Kowalskiego, obrażam Malinowskiego, bo oni się przyjaźnią.

Równie zabawnie brzmi w wykonaniu mojej Szanownej Polemistki próba retorsio argumenti (że kognitywni teoretycy metafory nie definiują pojęć, tylko je opisują):

Autor sam wykazuje sporą terminologiczną beztroskę, zapewne w myśl zasady, którą explicite wyraża zwrotem „mniejsza o nazwę” (s. 284-285).

Zastosowany przeze mnie zwrot, z którego E. Tabakowska wyciąga wniosek o „beztrosce terminologicznej" odnosił się do tego, czy w użytym przez Maxa Blacka terminie subsidiary subject (Black 1962) przymiotnik subsidiary tłumaczyć jako pomocniczy, wtórny, dodatkowy czy może jeszcze jakoś inaczej, co dla samego terminu jest bez znaczenia. Zupełnie czym innym jest tworzenie terminów bez ich definiowania.

Nie rozbawiło mnie natomiast, lecz wręcz przeciwnie - zasłużenie zawstydziło (na co było najwyraźniej obliczone, jako że do samej dyskusji nic istotnego nie wnosi) wytknięcie mi, że ,angielski termin vehicle Richardsa odpowiadający polskiemu określeniu nośnik jest konsekwentnie przywoływany z błędem ortograficznym”. Pokornie przyjmuję ten jakże dyskretny (jako że w nawiasie) przytyk Pani Profesor, ale nie zgadzam się, że „konsekwentnie”, bo właśnie niekonsekwentnie (por. np. na s. 28, 30), co jednak wskazywałoby na przyczynę leżącą raczej w niestarannej autokorekcie niż w prostym obskurantyzmie, co mnie oczywiście nie usprawiedliwia, ale łagodzi nieco zawartą w zarzucie sugestię.

Frontalnie natomiast zaatakowała Pani Profesor Tabakowska zaproponowaną przeze mnie klasyfikację metafor, przygotowując generalne natarcie stwierdzeniem:

[...] w efekcie terminologicznego zamieszania, metafora poetycka/kreatywna zostaje przez Autora przemianowana na metaforę tekstowa (przy czym nie musi to, jego zdaniem, być ani metafora "poetycka ani kreatywna”, s. 11), a następnie przeciwstawiona metaforze potocznej definiowanej z kolei jako metafora „skrajnie (?) sfrazeologizowana”. Jest ona różna od metafory językowej, która ze swej strony zostaje utożsamiona z metafora pojęciowa (s. 285).

Dosłownie nic w tym zdaniu nie odpowiada prawdzie. Ani metafora kreatywna nie jest na nic „przemianowana”, tylko jest, obok potocznej, odmianą metafory tekstowej (inaczej stylistycznej), która jest przeciwstawiona metaforze językowej, ani metafora językowa nie jest utożsamiana z pojęciową, ponieważ ta ostatnia mieści się pośrodku, na pograniczu językowej i tekstowej, obejmując wszystkie metafory językowe i część 
tekstowych (dwa pierwsze podtypy metafory obrazowej, o których piszą na s. 78 Lakoff i Johnson). Przy okazji przypominam Pani Profesor, że według klasyfikacji Stanisława Skorupki skrajnie sfrazeologizowane są stałe związki frazeologiczne, w przeciwieństwie do łączliwych, które są sfrazeologizowane częściowo.

Konkluzja po takim przygotowaniu artyleryjskim wydaje się oczywista:

Graf mający zilustrować tę skomplikowaną klasyfikację (Rys. 1, s. 12) dodatkowo cały zamęt powiększa [...] (s. 285).

Tylko że graf jest zupełnie jasny i przejrzysty, natomiast zamęt wprowadza jego tendencyjna interpretacja - przytoczona i skorygowana powyżej. Dla jasności wypada w tym miejscu pokazać (przypomnieć) czytelnikowi ten sporny graf (Cockiewicz 2013: 12):

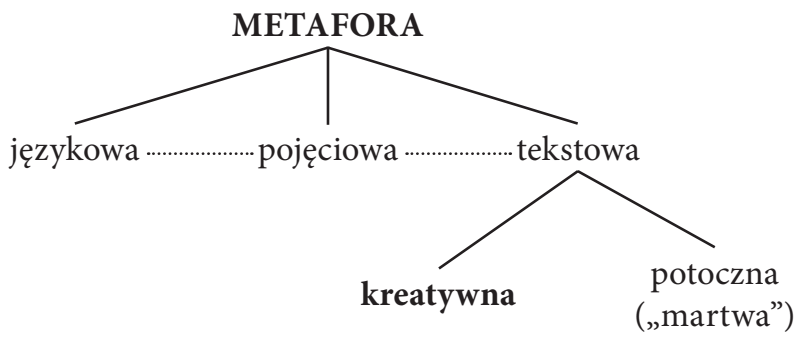

Porusza też Autorka ważną kwestię utożsamiania bądź nieutożsamiania, czy może częściowego utożsamiania, przez metaforę swoich dwóch fundamentalnych składników: tematu i nośnika, definiendum i definiensa, elementów domeny wyjściowej i docelowej... etc. (mniejsza o nazwę, bo we wszystkich teoriach, do których te terminy należą, chodzi o to samo). Stawia mi przy tym zarzut, że bezpodstawnie stosuję w moich analizach formułę ze znakiem równości między tematem a nośnikiem, ponieważ „metafora nie jest [...] relacją równoważności” (s. 286). To właśnie jest kwestią kontrowersyjną, bo oczywiście w realnej rzeczywistości nie zachodzi relacja identyczności między referentami tematu i nośnika metafory, ale na poziomie wyrażania mówiący/ piszący tak ją przedstawia, jakby zachodziła, i nie daje żadnych sygnałów niepełności tej identyfikacji. Zapewne dlatego autorzy kognitywnej teorii metafory stosują w tym miejscu leksem czasownikowy is, który w polskim tłumaczeniu został zastąpiony spójką zaimkową to, co nie robi istotnej różnicy. Przyznaję, że nie mam co do tej kwestii całkowitego przekonania, i to nie od czasu dyskusji, o której wspomina Pani Profesor (twierdząc, że robi to „gwoli prawdy”), w trakcie której miałbym jakoby się wycofać „z niefortunnego twierdzenia [...] zastępując ową »identyczność« mniej nieuzasadnionym, choć bardziej mylącym, terminem quasi-identyfikacja” (s. 286). "Gwoli prawdy", nigdy nie mówiłem o identyczności tylko o identyfikacji, a używany w książce termin tertium identificationis zastąpiłem terminem tertium quasi identificationis już w tekście tamtego referatu, a nie w dyskusji nad nim. Wątpliwości co do obu 
tych terminów mam w dalszym ciągu, gdyż przyznaję słuszność Pani Profesor, że oba są mylące, ponieważ każdy dotyczy innej perspektywy: jeden planu ekspresji, drugi semantyki, a dokładniej denotacji leksykalnej.

Z powodu reżimu objętościowego redakcji „LingVariów” (20 tys. znaków ze spacjami) do dalszych zarzutów stawianych mi przez Autorkę polemicznego artykułu muszę się odnieść selektywnie, wybierając ten, za pomocą którego ilustruje swoją opinię, że moja analiza jest nieprzekonująca i metodologicznie niepoprawna (s. 286). E. Tabakowska krytykuje moją interpretację wyrażenia metaforycznego Cośsrebrnego dzieje się $w$ chmur dali $\mathrm{z}$ dwóch powodów: za to, że w inwariantnej formule (elementarnym zdaniu metaforycznym) nie odróżniam akcji od zdarzenia, ponieważ piszę AKCJA/ZDARZENIE = przedmiot materialny, i za to, że jako podstawę (tertium comparationis) tej metafory wskazuję wyrażenia typu dzieje się coś ciekawego, strasznego etc., które za pomocą leksemu adiektywnego przypisują argumentowi zdarzeniowemu atrybuty przedmiotu.

Na pierwszy zarzut odpowiadam: rozróżniam, ale to rozróżnienie nie ma znaczenia dla tej metafory jako takiej i gdyby wyrażenie metaforyczne zawierało czasownik stało się (nazywające zdarzenie) zamiast dzieje się (nazywające proces) to metafora byłaby ta sama.

Drugi ze swoich zarzutów, ten dotyczący podstawy, Pani Profesor wzmacnia (retorycznym w zamierzeniu) pytaniem: „Czyż nie idzie tu raczej o rozumienie ogólnych pojęć akcji/zdarzenia i obiektu?” (s. 287). Odpowiem na nie jak na pytanie realne: oczywiście, że nie, bo ogólne pojęcia akcji/zdarzenia z jednej strony, a obiektu z drugiej są dla czytelnika całkowicie różne i nie mają ze sobą nic wspólnego, więc dlatego najpierw się zdziwi, jak to przeczyta, dopiero potem, jak sobie uświadomi, że są w języku połączenia z przymiotnikami typu coś strasznego, to zrozumie, że autor chciał powiedzieć to, co mówi cytowany niżej przez Prof. Tabakowską (na tej samej stronie tylko nieco dalej) Vyvyan Evans, że ZDARZENIA TO RUCHOME OBIEKTY. A teraz ja zadam mojej Szanownej Oponentce pytanie (też retoryczne w zamierzeniu, acz niekoniecznie w praktyce): Co jest poprawne metodologicznie: pokazać najpierw, dlaczego AKCJA/ZDARZENIE TO PRZEDMIOT MATERIALNY, czy wygłosić tezę ZDARZENIA TO RUCHOME OBIEKTY bez żadnego uzasadnienia?

W tym momencie przekroczyłem już 18950 znaków, więc żeby się zmieścić (z abstraktem i skromną bibliografią), muszę zakończyć niniejszy dyskurs, może taką oto pointą, nawiązującą do bardzo kreatywnej metafory użytej przez Panią Profesor w tytule Jej artykułu, w której mowa o wierności i uciążliwości: w niniejszej mojej odpowiedzi też rzecz idzie o wierność i uciążliwość, a sprowadza się do refleksji, że kiedy się krytykuje czyjąś wypowiedź, to brak wierności wobec tekstu bywa uciążliwy nie tylko dla krytykowanego, ale i dla tego, kto to czyta, w końcu zaś niekiedy i dla samego krytyka. Myśl tę dedykuję z wyrazami najgłębszego szacunku mojej Szanownej Oponentce. 


\section{Literatura}

BLACK M., 1962, Models and Metaphors. Studies in Language and Philosophy, Ithaca.

Cockiewicz W., 2011, Metaforyka Leśmiana (Analiza lingwistyczna), „Biblioteka »LingVariów«" t. 13, Kraków.

JÄKEL O., 1997/2006, Metafory w abstrakcyjnych domenach dyskursu, Kraków.

Korwin-Piotrowska D., 2006, Powiedzieć świat. Kognitywna analiza tekstów literackich na przykładach, Kraków.

LAKoff G., Johnson M., 1980/1988, Metafory w naszym życiu, Warszawa.

Libura A., 1998, Ograniczenia w zastosowaniu kognitywnej teorii metafory do analizy metafor poetyckich, [w:] E. Jędrzejko (red.), Nowe czasy, nowe języki, nowe (i stare) problemy, „Prace Naukowe Uniwersytetu Śląskiego w Katowicach” nr 1720, Katowice, s. 219-230.

\section{On faithfulness and nuisance, and just by the way, on metaphor (A reply to prof. Elżbieta Muskat-Tabakowska's criticism) Summary}

The present paper is a reply to a polemic published by prof. Elżbieta Muskat-Tabakowska under the title Pies wierny, ale uciążliwy, czyli o metaforze (Leśmiana i nie tylko) ('A dog loyal but tiresome: on metaphor in Leśmian's poetry and beyond'), in which she critically reviews this authors book Metaforyka Leśmiana. Analiza lingwistyczna ('Metaphors in Leśmian's poetry (A linguistic analysis)'). Most importantly, this paper rejects the principal accusation that the book is but a manifestation of its author's dislike of the cognitive theory of metaphor. It also rebuts a series of minor complaints by showing that they are based on subjective interpretations and arbitrary assessments which are inconsistent with the letter of the text, and not supported by any proof. The author explains why he believes that the cognitive theory of metaphor is unhelpful in the empirical analysis of data. 